\title{
Study The Severe Effects of Iron Compounds Presenting in Sandstone on the Deterioration of Wall Paintings of Archaeological Tombs in Bahariya Oasis - Egypt
}

\author{
Rabea Radi Abdel Kader', Shaimaa Sayed Mohamed El-Sayed ${ }^{2}$, Ahmed Abo-El Yamin ${ }^{3}$ \\ ${ }^{1}$ Researcher and General Manager of Presidential Museums and palaces Restoration Authority - Ministry of \\ Antiquities, Egypt. \\ ${ }^{2}$ Lecturer, Conservation Department, Faculty of Archaeology, Luxor University, Egypt. \\ ${ }^{3}$ Manager of Sohag's Antiquities Restoration Authority-Ministry of Antiquitie, Egypt. \\ Egyptianconservators2013@gmail.com
}

\begin{abstract}
The Wall paintings in Bahariya oasis expose to various deterioration factors, especially the resulted deterioration from the geological nature of sandstones' supports; sandstone of Bahariya formation is considered the weakest sandstone type in Egypt because of its geological formation which contains a very big percentage of iron oxides. Sandstone samples were taken, analyzed and examined by $x$-ray diffraction and scanning electron microscope, the iron oxides are thecement material in sandstone which affect negatively on the wall paintings in the selected tombs (Badi-Ishtarand Bannantiu tombs), they caused a lot of deterioration phenomena to the wall painting layers like: layers loss,black spots, cracking through all the layers and sandstone support weakness that threatens the remaining wall paintings and the safety of the tombs. Iron oxides percentage in Badi-Ishtartomb is more than Bannantiu tomb and this is reflected on the wall paintings case in Badi-Eshtar. This research sheds the light on this phenomenon and its effect on the wall painting's deterioration.
\end{abstract}

Keywords : iron compounds; deterioration; bahariya oasis; wall paintings; archaeological tombs.

\section{Introduction}

\subsection{Historical Description of the Chosen Tombs}

\section{a. Badi-Ishtar tomb}

The history of this tomb is belonged to the 26th dynasty in Sheikh SawbiArea Bahariya oasis, Badi- Ishtar was the biggest priest of the worshiped "Khonsu" and the worshiped "Horus".

\section{b. Architectural Description of the tomb}

The remains 1of the views in this tomb expressed religious subjects like: festivals in the dead'sbook. The Entrance of the tomb is in the North and the visitor can reach forit bya well. The closet above the tomb was completely disappeared, the tomb consists of a hall with four columns, the tomb's ceiling is vaulted and there are also three small rooms.The original coffin is between the columns and beside this coffin, there are two stone coffins in the smallhall returned to the Roman's era (figure 1).

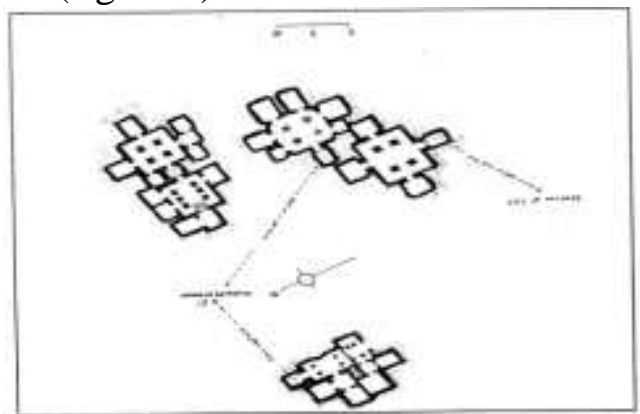

Figure 1. The plan of Badi- Ishtar tomb 


\subsection{Bannantiu tomb}

This tomb is locatedin the Eastern area of Bawiti "Kasr- Selim area - Bahariya oasis" ;Bannantiu was a rich merchant in the $26^{\text {th }}$ dynasty.

\subsection{Architectural description of the tomb}

The closet of the tomb was completely disappeared, the visitor can reach to the burialroom by a well with 6 metersdepth, in the end of the well, there are two entrances, the first opens in South and leads to incomplete tomb empty from ornaments, the historians believed that this tomb was for his wife's burial-fig (2), the views of Bannantiu tomb expressed religious subjects also like: the moon and the sun's journey, the most important view in the tomb is Bannantiu stood opposite the god in the court of heart's weight. The tomb was discovered by Ahmed Fakhry in 22 April 1983, he took some photos for all the views in the tomb .Aftera year, he opened it again and found some black spots on the views and some scripts which were written with black ink on yellow backgrounds started to be dull, thisphenomenon because of the existence of iron oxides in the sandstone support.

\section{Review of Literature}

\subsection{The Sandstone Geological Nature in Bahariya Oasis:}

There are two types of sandstone in El-Bahariya oasis:

a. Nubian sandstone:A

This stone contains various hard iron nodules, shells and fossils, the stone's mineral composition includes "micaceous minerals", the stone is named in this case " micaceous sandstone" besides the micaceous minerals, there are gypsum crystals and pyrite crystals( $\left.\mathrm{FeS}_{2}\right)$ which are considered the cement material for quartz crystals "the main mineral of the sandstone $\mathrm{SiO}_{2}$ " silicone di- oxide".

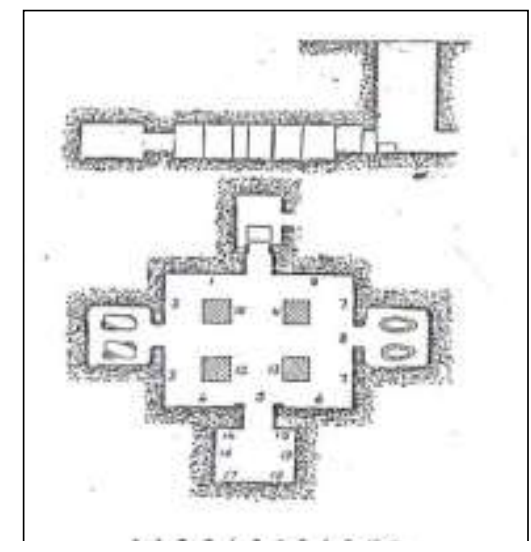

Figure 2. The plan of Bannantiu tomb

\section{b. Dolomitic Sandstone}

The mineral composition of this stone contains dolomite " $\mathrm{Ca} \mathrm{Mg}\left(\mathrm{CO}_{3}\right)_{2}$ "Calcium, magnesium carbonates ", gypsum crystals and clay minerals withdark yellow color and fossils. GoethiteFeO $(\mathrm{OH})$ is the cement material of the quartz grains. Hematite and magnetite are 
considered the most important minerals for iron ores which are found in thin layers with silicate rocks.

\section{Materials and Method}

First,samples were taken from sandstone' supports from the rock - cut tombs "Badi Ishtarand Bannantiu", they were analyzed by "X-Ray Diffraction"XRD, thenexamined with" Scanning Electron Microscope "SEM" (figure 3-6).

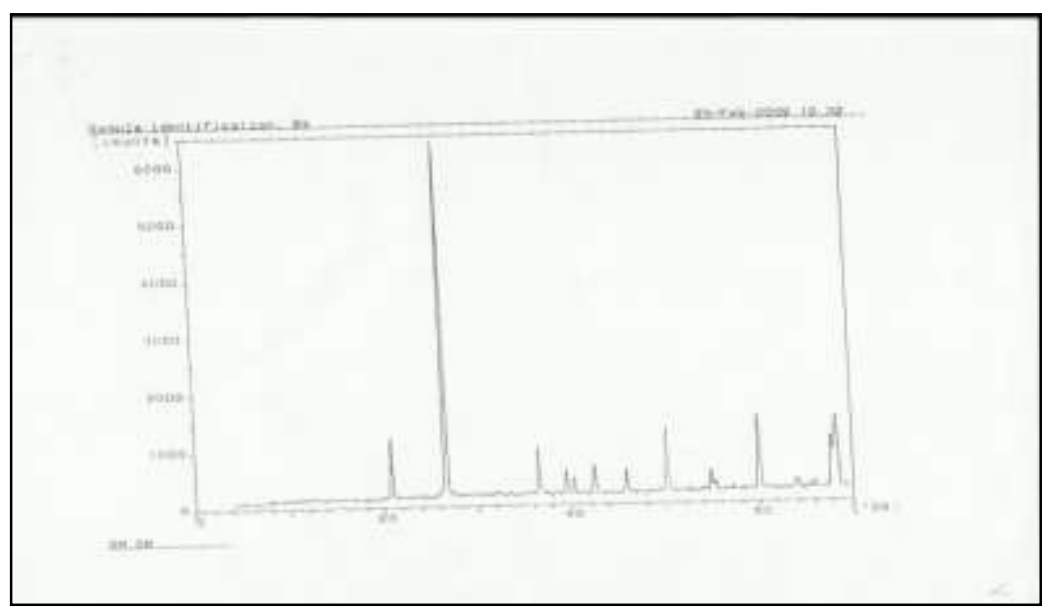

Figure 3. XRD pattern of the sandstone's sample from Badi-Ishtartomb

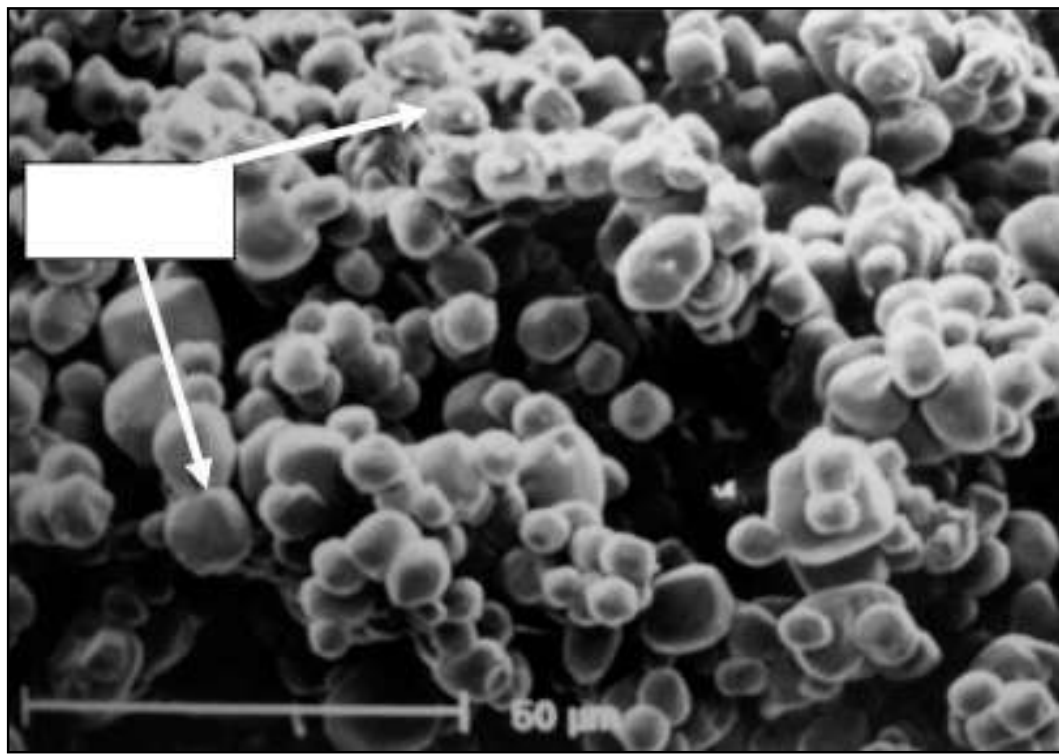

Figure 4. The SEM examination of the previous sample 


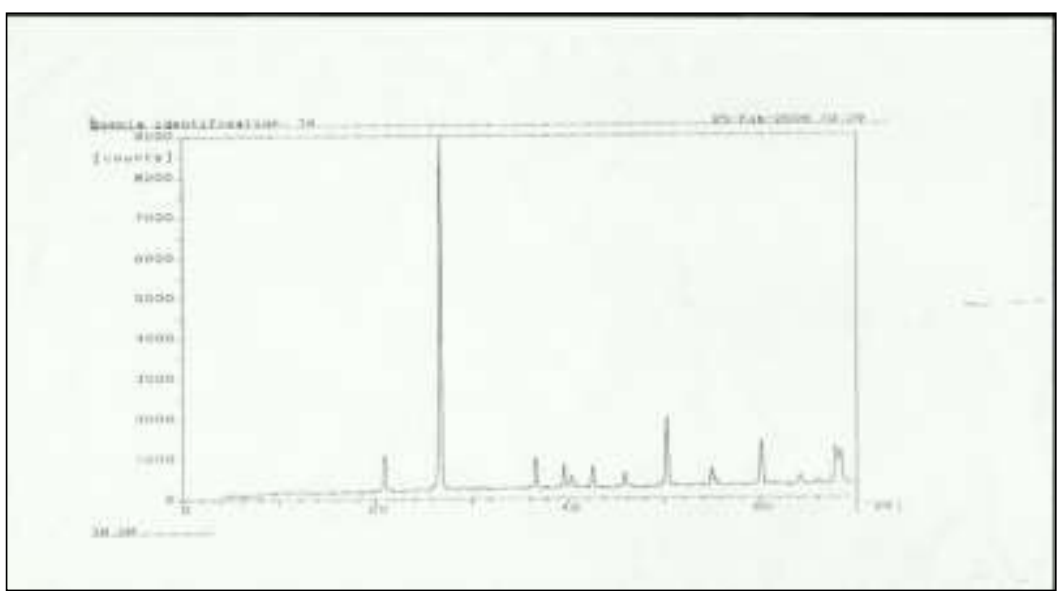

Figure 5. XRD pattern of the sandstone sample from Bannantiu's tomb

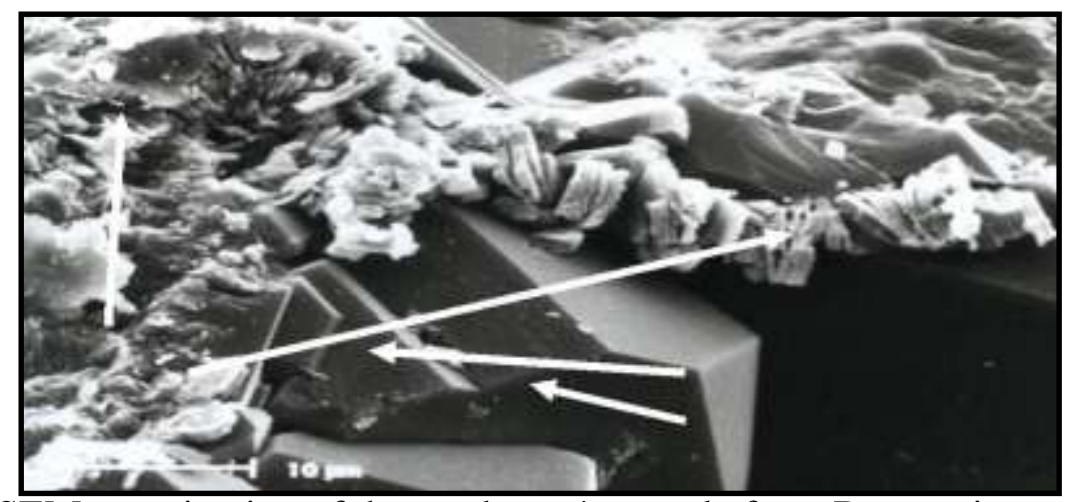

Figure 6 The SEM examination of the sandstone's sample from Bannantiu tomb (Arrows refer to the iron compounds)

After that,air temperature degrees and relative humidity percentages were measured and registered inside and outsidethe selected tombs(in the period of January to July 2012); they were as follows in (table No.2), the source of humidity in the tombs is air humidity and drainage water.

\section{Discussion}

Table 1. Results of XRD analysis and SEM examination of the mother rock "wall painting" supports" of Badi - Ishtar and Bannantiu tombs.

\begin{tabular}{|c|c|c|}
\hline Tomb Name & XRD Results & SEM examination \\
\hline Badi-Ishtartomb & $\begin{array}{l}\text { 1- The Major compound is Quartz } \\
\text { "SiO } \mathrm{SiO}_{2} \text { approximately } 69.35 \% \\
2-\text { The Second compound is } \\
\text { Wuestite" iron oxide" FeO" } \\
\text { approximately } 14.1 \% \\
3-\text { The Third compound is Goethite } \\
(\alpha-\mathrm{Fe} \mathrm{O}(\mathrm{OH})) \text { approximately } \\
12.14 \%\end{array}$ & $\begin{array}{l}\text { Scanning Electron } \\
\text { Microscope (SEM) } \\
\text { examination presents the } \\
\text { existence of clay minerals } \\
\text { beside iron oxides which } \\
\text { means the severe } \\
\text { deterioration of wall } \\
\text { paintings in high humid } \\
\text { conditions. The clay }\end{array}$ \\
\hline
\end{tabular}




\begin{tabular}{|c|c|c|}
\hline & $\begin{array}{l}\text { 4 The Fourth compound is Feroxyhite } \\
\text { "iron oxides and hydroxides" } \\
\text { approximately } 4.4 \% \text {. } \\
\text { The total iron compounds are } \\
\text { approximately } \mathbf{3 0 . 6 4 \%} \text { of the total } \\
\text { compounds percentage, which affect } \\
\text { badly on the sand stone support } \\
\text { because of their solubility in water- } \\
\text { fig (3) }\end{array}$ & $\begin{array}{l}\text { minerals will absorb water } \\
\text { and swell, when water } \\
\text { evaporates in high air } \\
\text { temperature degrees, the } \\
\text { clay minerals will shrink. } \\
\text { The cycles of swelling and } \\
\text { shrinkage will cause the } \\
\text { severe deterioration to the } \\
\text { wall painting layers beside } \\
\text { the iron oxides dissolution } \\
\text { - fig (4). }\end{array}$ \\
\hline Bannantiu tomb & 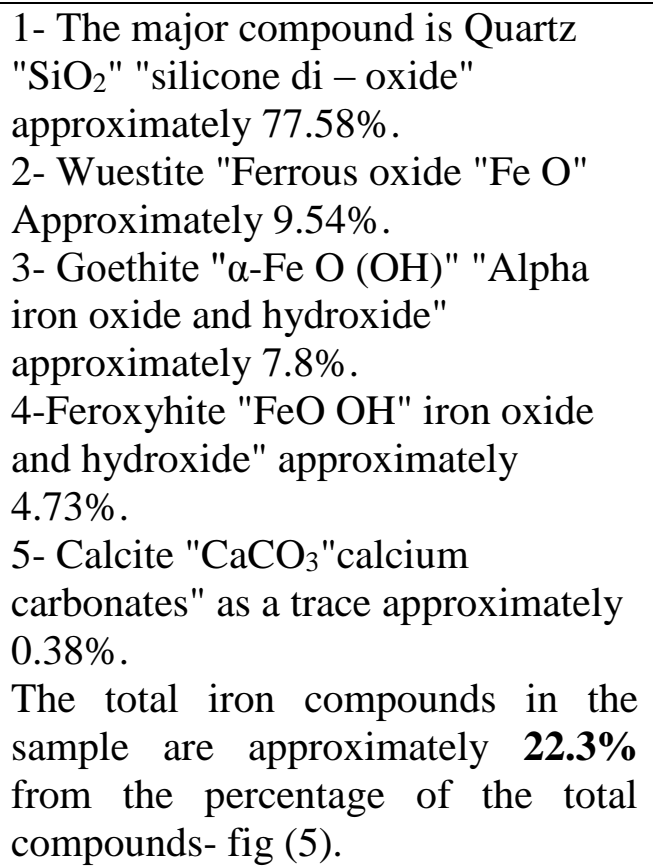 & $\begin{array}{l}\text { It was found from the } \\
\text { scanning electron } \\
\text { microscope examination } \\
\text { that the sample contained } \\
\text { clay minerals in its content, } \\
\text { which will affect badly with } \\
\text { iron oxide dissolution on } \\
\text { the safety of the } \\
\text { Bannantiu's tomb - fig (6). }\end{array}$ \\
\hline \multicolumn{3}{|c|}{$\begin{array}{l}\text { By the comparison between the iron compounds in the two samples, it was noticed that } \\
\text { iron compounds ' percentage in the sample from Bannantiu tomb was approximately } \mathbf{2 2 . 3} \\
\% \text {, while the percentage in the sample from Badi-Ishtarwas approximately } \mathbf{3 0 . 6 4 \%} \text {. }\end{array}$} \\
\hline
\end{tabular}

Table 2. Air temperature degrees and relative humidity percentagesinsideandoutside the selected tombs

\begin{tabular}{|c|c|c|c|c|c|c|c|c|}
\hline $\begin{array}{l}\text { Local clin } \\
\text { outside }\end{array}$ & & $\begin{array}{l}\text { Local Cl } \\
\text { inside }\end{array}$ & & \multirow{4}{*}{$\sum_{\Sigma}^{\text {를 }}$} & \multirow{4}{*}{ 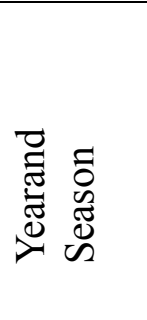 } & \multirow[b]{4}{*}{ 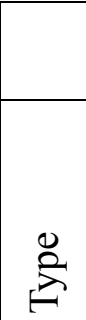 } & \multirow{4}{*}{ 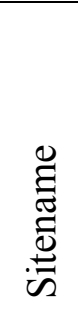 } & \multirow{4}{*}{ 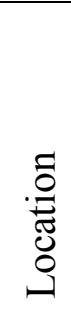 } \\
\hline & tombs & & tombs & & & & & \\
\hline Average & Average & Average & Average & & & & & \\
\hline $\mathrm{Rh} \%$ & Temp. C & $\mathrm{Rh} \%$ & $\begin{array}{l}\text { Temp. } \\
\text { C }\end{array}$ & & & & & \\
\hline 55 & 12 & 40 & 15 & Jan. & Winter & & & \\
\hline 52 & 14 & 39 & 17 & Feb. & 2012 & & & \\
\hline
\end{tabular}




\begin{tabular}{|c|c|c|c|c|c|c|c|}
\hline 30 & 40 & 66 & 17 & June & Summer & & \\
\hline 29 & 42 & 69 & 18 & July & 2012 & & \\
\hline 50 & 18 & 39 & 19 & Jan. & Winter & \multirow{4}{*}{$\begin{array}{l}\frac{1}{2} \\
\frac{1}{8} \\
0 \\
0\end{array}$} & \multirow{4}{*}{  } \\
\hline 48 & 17 & 40 & 20 & Feb. & 2012 & & \\
\hline 31 & 40 & 67 & 18 & June & Summer & & \\
\hline 30 & 41 & 66 & 19 & July & 2012 & & \\
\hline
\end{tabular}

The high percentage of iron oxides in sandstone supports affect badly on the wall paintings in Bannantiu and Badi - Ishtartombs, the results explain the big danger of losing wall paintings in Badi -Ishtartomb comparing to Bannantiu tomb "The sandstone in BadiIshtartomb is weaker than the sandstone in a Bannantiu tomb", also there are many sources of humidity in the tombs like: air humidity and drainage water.

\subsection{The effects on the selected tombs are as follows:}

a. The Effect of iron compounds increase on the deterioration of Badi-Eshtar' wall paintings:

- Cracks in walls and ceiling of the tomb because of the sand stone's weakness, iron compounds dissolve in high humidity and the sandstone becomes very weak because of cement material's loss "sand stone bleeding" (figure 7-8).

- Partial separation between the wall painting' layers and the sandstone support "drumming phenomenon".

- Losing of the wall paintings' layers because of bleeding of the support (figure 9).

- Black spots deform the views of the wall painting because of the dissolution of iron oxides in high humidity content which went out on the wall paintings and deform them (figure 10).


Figure 7-8. cracks in one of the tomb's wall because of sandstone weakness 


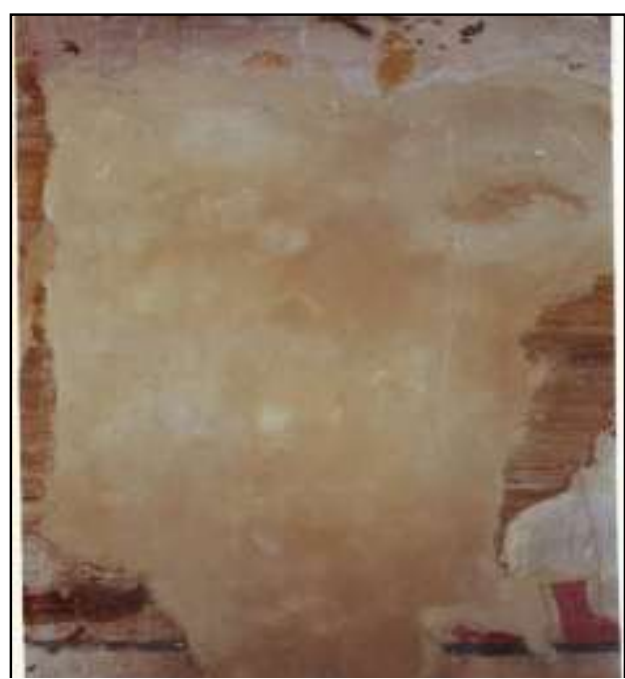

Figure 9. A Completely loss of the wall paintings' Layers which were completed with a Mortar consisted of sand and lime 4:1 with Namix"adhesive material"

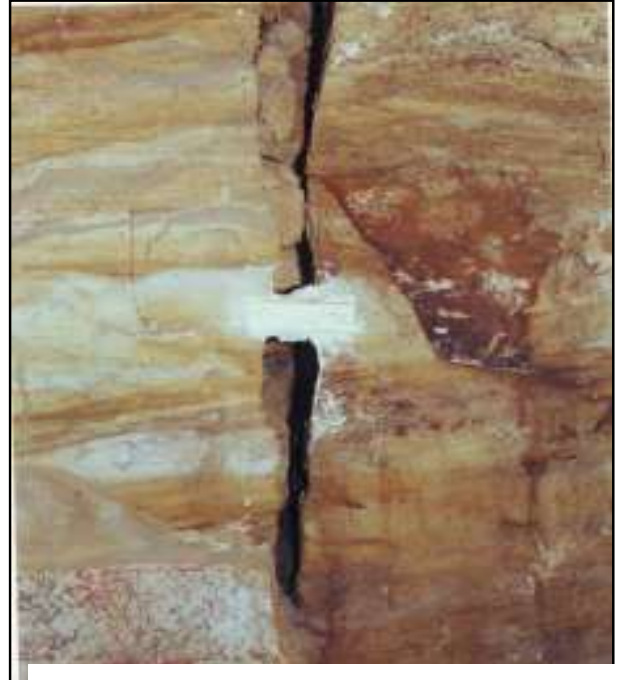

Figure 10. The Deformation of the wall paintings with black iron spots

\subsection{The Effect of iron compounds increase on the deterioration of Bannantiu wall paintings}

a. Black spots on wall painting layers especially the colorful layer because of the migration of dissolved iron compounds in high humidity content on one hand but on the other hand, in low humidity content the water which united with the iron compounds evaporates causing the black spots (figure 11-12)

b. Losing of the wall paintings layers because of sandstone bleeding.

c. Falling of plaster layers because of their weakness figure 13.

d. Macro and micro cracks in the plaster layers figure 14.

e. Some pigments like yellow becomes dull- figure 15-16.

f. Nabil (2000) mentioned that the pigments in Badi- Ishtarand Bannantiu wall paintings were:

- The source of pigments ' medium was Arabic gum .

- The source of black pigment was carbon grains .

- The source of red pigment was Hematite.

- The source of yellow pigment was Geothite.

- The source of blue pigment was (The Egyptian blue) (Calcium and Copper Silicates $\left(\mathrm{CaCuSi}_{4} \mathrm{O}_{10}\right)$.

- He mentioned also that the plaster of the wall painting in the tombs was (Gypsum plaster).

a. The presence of iron oxidesin the support will accelerate the deterioration of the organic medium (Arabic gum) in high relative humidity because the presence of iron oxides accelerate the chemical reactions, they perform as agents in chemical reaction.

b. It was noticed that the black spots increased in the area of yellow and red pigments because they consistedofiron oxides in the nature, beside thedissolution ofiron 
Budapest International Research in Exact Sciences (BirEx) Journal

Volume 1, No 3, July 2019, Page: 5-13

e-ISSN: 2655-7827 (Online), p-ISSN: 2655-7835 (Print)

www.bircu-journal.com/index.php/birex

emails: birex.journal@gmail.com

birex.journal.qa@gmail.com

oxides in the supportin the presence of high relative humiditythat caused the concentration ofblack spots on these areas .

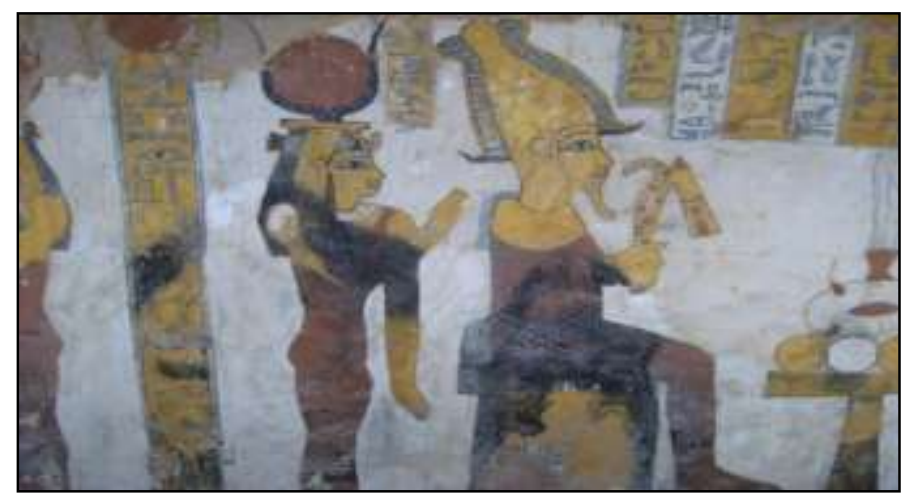

Figure 11. Black spots on the colorful painting layer

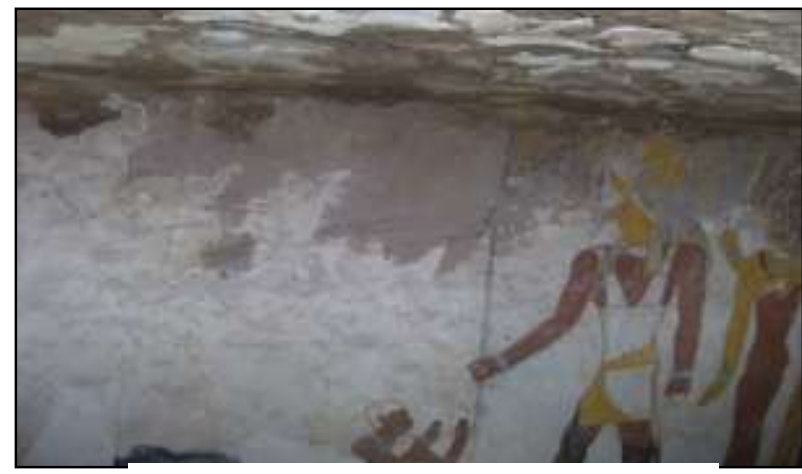

Figure 13. Falling of plaster layers because of their weakness

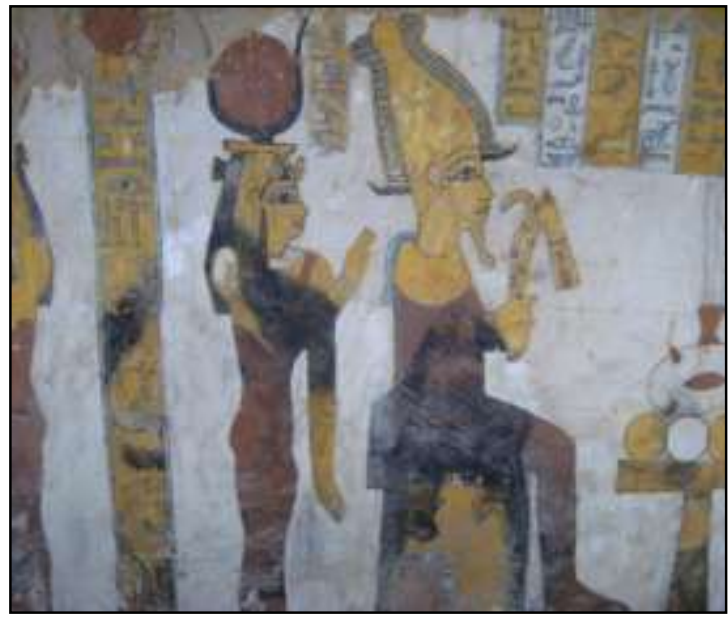

Figure 15. The yellow pigment becomes dull



Figure 12. Black spots' migration through the colorful layer

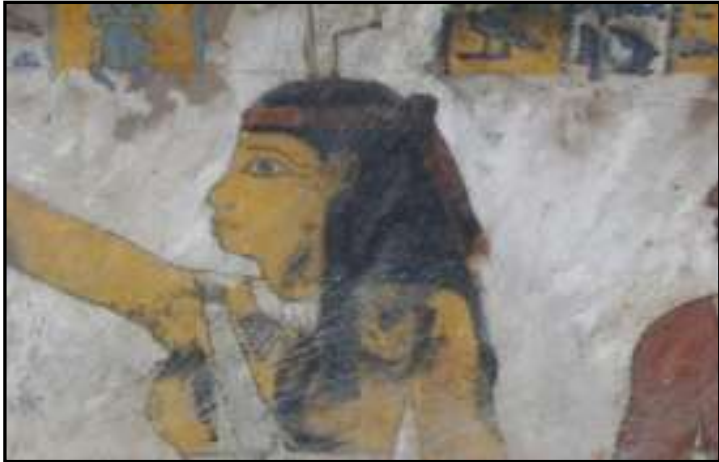

Figure 14. Cracks in the wall painting plaster layers

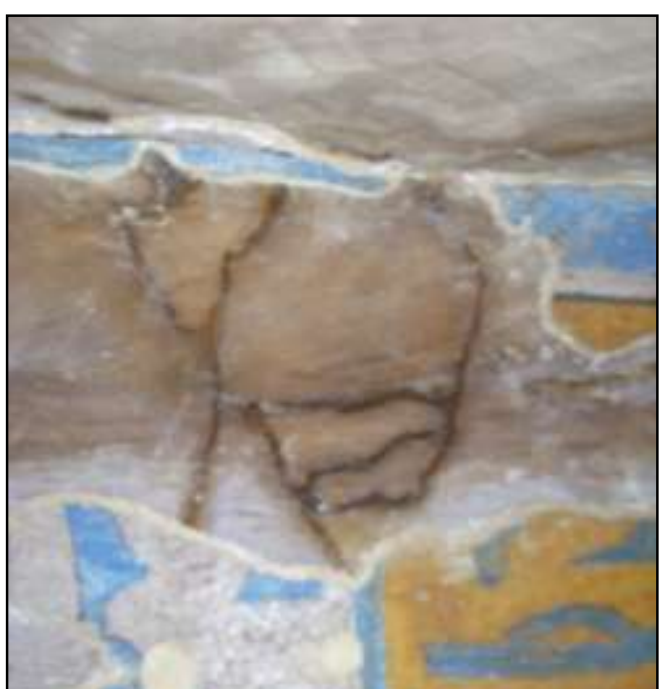

Figure 16. Iron veins in the sand stone support under the wall painting layers 


\section{Conclusion}

Iron oxides presenting in Sandstone ' supports have a severe effect on the deterioration of wall painting ' layers because of their dissolution in high humidity which cause the sandstone's weakness and bleeding,the deformation of colorful layers with black spots and the result is the loss of wall painting layers and the precious cultural heritage in the end.

The high humidity in the tombs is the main deterioration factor beside the geological nature of sandstone, there are many sources of humidity like: air humidity and drainage water, and that's mean the dissolution of iron oxides.

\section{Acknowledgement:}

To Bahariyaoasis Antiquities' Restoration Department - Ministry of Antiquities - Egypt.

\section{References}

Ahmed Fakhry, El-Wahat El-Bahariya (Vol.2- Bahariya and Farfara oases ), Supreme council of antiquities printing presses ,Cairo, pp. 144-146.

Ahmed Fakhry, opcit, p. 159.

Rosewood, B., "The Tomb of Bannantiu in the Bahariya Oasis",2005@www.tour Egypt.net. Hawass, Z., "The discovery of the valley of the golden mummies at Bahariyaoasis"@ http://guardians.net.

Mason,B.J.," Acid rain its causes and its effects on inland water" , Clarendon Press, Oxford, New York, 1992, p. 15

Nabil Ahmed Abdel Tawab , " A study of treatment of mural paintings carried out on a sandstone supports in El - Bawaiti tombs - Bahariya oasis applied on a chosen tomb, Master thesis , Restoration department, Faculty of Archaeology , Cairo university , Egypt, 2000, pp.69-70.

Nabil Ahmed Abdel Tawab, opcit, p. 296.

Thomas, H.H.,etal., "Geology of ore deposits ", second edition, Edward Arnold, London, pp. 36-39 